\title{
Anesthesia for minimally invasive surgery
}

$\mathrm{T}$

HIS review summarizes the anesthetic implications of minimally invasive surgery, a term which encompasses many surgical procedures that use indirect visualization and instrumentation. Many of these procedures are not new: descriptions of laparoscopy date back to the early 1900 s (Berci). ${ }^{1}$ It is the recent technological advances in fibre-optic cabling as well as microsurgical instrumentation that have allowed the use of these techniques for a myriad of more complex procedures. However, this technology is expensive and would not likely have been adopted without the understanding and perception of their benefits by the public (Nash). ${ }^{2}$ This review will begin with a description of laparoscopy since it is the most widely studied and understood minimally invasive procedure and will then highlight other procedures, noting the specific variations between these procedures and laparoscopy.

\section{Laparoscopic surgery}

Lower abdominal, mainly gynecological, laparoscopic surgery has been routinely performed since the 1970s. It was the improved instrumentation that allowed laparoscopic cholecystectomy to revolutionize upper abdominal surgery in the 1990s. Now, laparoscopically-performed gastro-esophageal, hepato-biliary, colo-

TABLE I Comparison of laparoscopy and laparotomy for cholecystectomy

\begin{tabular}{|c|c|c|}
\hline Variable & Laparoscopy & Laparotomy \\
\hline \multicolumn{3}{|l|}{$\begin{array}{l}\text { Intraoperative } \\
\text { respiratory changes }\end{array}$} \\
\hline lung volumes & t+ & + \\
\hline compliance & t+ & + \\
\hline cardiovascular changes & ++ & + \\
\hline positioning & reverse Trendelenburg & supine \\
\hline $\mathrm{CO}_{2}$ absorption & ++ & - \\
\hline \multicolumn{3}{|l|}{ Postoperative } \\
\hline pain & + & ++ \\
\hline pulmonary dysfunction & + & ++ \\
\hline metabolic response & + & t+ \\
\hline nausea and vomiting & ++ & + \\
\hline
\end{tabular}

rectal, herniorrhaphy, as well as splenic procedures, are routinely performed using minimally invasive approaches. ${ }^{3}$ This change has occurred for the reasons that are summarized in Table I. Essentially, the postoperative complications of pain, pulmonary dysfunction, metabolic response, fatigue, and prolonged hospital stay that occur with laparotomy, are minimized with laparoscopy at the cost of increased intraoperative pathophysiology involving the cardiorespiratory systems, carbon dioxide absorption, and patient positioning. ${ }^{4}$ These intraoperative changes initially resulted in laparoscopic cholecystectomy being contraindicated in patients with either cardiopulmonary disease, or morbid obesity. ${ }^{5}$ However, with the recognition of the improved postoperative outcome, laparoscopic cholecystectomy is now the procedure of choice for patients with cardiopulmonary disease.

\section{(i) Pulmonary effects}

The pulmonary changes that occur during laparoscopic procedures are mostly related to patient positioning and the creation of a pneumoperitoneum. Creation of the pneumoperitoneum (which should be limited to $15 \mathrm{~mm} \mathrm{Hg}$ ) leads to decreased lung volumes which potentially create small airway collapse and hypoxia. The pneumoperitoneum also decreases compliance increasing the work of breathing thus making ventilation more difficult. Furthermore, the pneumoperitoneum is created with carbon dioxide $\left(\mathrm{CO}_{2}\right.$ see below), which is readily absorbed and must be excreted by the lungs. This further increases the ventilatory demands, as well as leading to increased sympathetic nervous system output. Patient positioning, which for lower abdominal surgery involves the Trendelenburg (head-down position), further decreases lung volumes and increases the work of breathing from a respiratory perspective. For upper abdominal surgery, the reverse Trendelenburg (head-up) position is used, which somewhat counterbalances the effect of pneumoperitoneum by increasing lung volumes and decreasing the work of breathing. The net result of the pneumoperitoneum and reverse Trendelenburg position from a ventilatory perspective, is an increase in

Department of Anesthesia, London Health Sciences Centre, University Campus, and the University of Western Ontario, 339 Windermere Road, London, Ontario N6A 5A5 Phone: 519-663-3022, Fax: 519-663-3079; E-mail: nbadner@julian.uwo.ca 
the arterial carbon dioxide partial pressure $\left(\mathrm{PaCO}_{2}\right)$ and end-tidal carbon dioxide partial pressure $\left(\mathrm{P}_{\mathrm{ET}} \mathrm{CO}_{2}\right)$ of approximately $8 \mathrm{~mm} \mathrm{Hg}$ and a decrease in $\mathrm{pH}$ of 0.01 units. ${ }^{4}$ This is accompanied by an approximately $10 \mathrm{~cm}$ of $\mathrm{H}_{2} \mathrm{O}$ increase in plateau airway pressure as well as a $\mathbf{5 0 \%}$ reduction in lung compliance. These changes are easily compensated with mechanical controlled ventilation when anticipated.

\section{(ii) Cardiovascular changes}

From a cardiovascular perspective, the pneumoperitoneum both decreases venous return thereby decreasing cardiac index, while at the same time increases systemic vascular resistance and thus increases mean arterial pressure. The Trendelenburg position leads to increased venous return and increased stroke volume while the reverse Trendelenburg position further worsens the pneumoperitoneum induced cardiovascular changes by decreasing venous return even further. As noted, the increased intraabdominal pressure leads to both a decrease in venous return as well as an increase in systemic vascular resistance. ${ }^{4}$ This effect is seen within five minutes of pneumoperitoneum and, although the effects decrease with time, they are still present $30 \mathrm{~min}$ following the initiation of pneumoperitoneum. This leads to the creation of a situation where the cardiac index is depressed, yet the mean arterial pressure is elevated. Patients with severe cardiovascular disease and left ventricular dysfunction may require invasive monitoring with arterial and pulmonary artery catheters.

TABLE III Characteristics of gases used to create pneumoperitoneum

\begin{tabular}{|c|c|c|c|c|c|c|}
\hline & $\begin{array}{l}\text { Carbon } \\
\text { Dioxide }\end{array}$ & $\begin{array}{l}\text { Nitrous } \\
\text { Oxide }\end{array}$ & Air & Argon & Helium & Oxyegen \\
\hline water solubility & yes & no & no & no & no & no \\
\hline combustible & no & yes & yes & no & no & yes \\
\hline inert & no & yes & yes & yes & yes & no \\
\hline irritation & yes & no & yes & no & no & yes \\
\hline
\end{tabular}

\section{(iii) Complications}

There are some complications that, while not unique for laparoscopic abdominal surgery, are more prevalent with these procedures. These include endobronchial intubation, pneumothorax, subcutaneous emphysema and massive $\mathrm{CO}_{2}$ embolism. Their onset can be sudden with life-threatening consequences. Their differentiation is determined by assessment of the capnograph, pulse oximeter, and airway pressure and is summarized in Table II.

Endobronchial intubation can occur intraoperatively and is usually temporally related to changes in patient positioning, especially with the introduction of pneumoperitoneum and Trendelenburg positioning. ${ }^{6}$ The resulting increased airway pressure and desaturation therefore usually occurs early in the procedure and without an increased $\mathrm{P}_{\mathrm{ET}} \mathrm{CO}_{2}$.

The development of a pneumothorax usually occurs later in the procedure and is associated with a rise in the $\mathrm{P}_{\mathrm{ET}} \mathrm{CO}_{2}$, as well as associated subcutaneous emphysema and is more common with procedures involving the esophagus. ${ }^{7}$ The classic treatment of pneumothorax is insertion of a chest tube. However, based on their large series, Joris et al. have recommended an initial trial of increasing the inspired oxygen concentration, discontinuation of nitrous oxide and the addition of positive end expiratory pressure. ${ }^{4}$ This recommendation is made since the placement of chest tubes will drain the pneumo-peritoneum and make the surgical procedure virtually impossible to complete.

Significant subcutaneous emphysema can also occur independently, though usually later in the procedure, and also is more prevalent with procedures involving the esophagus. It leads to a sudden rise in $\mathrm{P}_{\mathrm{ET}} \mathrm{CO}_{2}$, however without changes in arterial oxygen saturation or airway pressures. The rise in arterial carbon dioxide can be quite rapid and large, with changes occurring within $30 \mathrm{~min}$. These changes resolve quite quickly postoperatively and usually resolve within $120 \mathrm{~min} .{ }^{8}$

Lastly, although small microemboli of carbon dioxide are quite common, as recorded using transesophageal echocardiography, massive carbon dioxide embolism sufficient to obstruct the pulmonary out-

TABLE II Algorithm allowing for the differentiation of serious complications of laparoscopic surgery

\begin{tabular}{lllll}
\hline capnography & $\pm \mathrm{P}_{\mathrm{ET}} \mathrm{CO}_{2}$ & $\uparrow \mathrm{P}_{\mathrm{ET}} \mathrm{CO}_{2}$ & $\uparrow \mathrm{P}_{\mathrm{ET}} \mathrm{CO}_{2}$ & $\downarrow \mathrm{P}_{\mathrm{ET}} \mathrm{CO}_{2}$ \\
oximetry & $\downarrow \mathrm{SaO}_{2}$ & $\downarrow \cdot \mathrm{SaO}_{2}$ & - & $\downarrow \mathrm{SaO}_{2}$ \\
airway pressure & $\uparrow \mathrm{PAW}$ & $\uparrow \mathrm{PAW}$ & - & - \\
other & $\downarrow$ air entry & $\downarrow$ air entry & crepitus & murmur, \\
& $\begin{array}{l}\text { BP } \\
\text { diagnosis }\end{array}$ & pneumothorax & subcutancous & $\begin{array}{l}\mathrm{ECG} \text { changes } \\
\text { massive CO }\end{array}$ \\
& $\begin{array}{l}\text { endobronchial } \\
\text { intubation }\end{array}$ & & emphysema & embolism \\
\hline
\end{tabular}


flow tract is quite rare. When it does occur, there is usually a sudden decrease in $\mathrm{P}_{\mathrm{ET}} \mathrm{CO}_{2}$ combined with a rapid fall in oxygen saturation, without changes in airway pressure. ${ }^{9}$

\section{(iv) Visualization}

As indicated, surgeons require the creation of a pneumoperitoneum to allow visualization of abdominal viscera. The gas presently utilized for this is carbon dioxide. This gas is chosen because of its high water solubility, thus allowing easy excretion of absorbed gas via the lungs, as well as minimizing the effects of gaseous emboli. It is also non-combustible allowing for the use of cautery (Table III). Use of nitrous oxide, air and oxygen have been largely abandoned because of their ability to support combustion. Recent experimentation has centred around the use of the inert gases, helium and argon, because of their non-combustibility and lack of abdominal irritation. These gases are also extremely insoluble creating potential problems if gaseous emboli occur. Animal studies which compared the use of inert gases with carbon dioxide to create a pneumoperitoneum showed that the inert gases were much more dangerous when gaseous emboli formed. ${ }^{8,10}$ The most recent innovation is the use of an abdominal wall retractor which lifts the abdominal wall allowing visualization of the viscera without use of a pneumoperitoneum. ${ }^{11-13}$ The use of this retractor avoids the problems of decreased pulmonary compliance and lung volumes, avoids the carbon dioxide load, and minimizes changes in venous return and systemic vascular resistance. Whether this device becomes surgically acceptable remains to be seen.

\section{(v) Outcomes}

The change from open laparotomy to laparoscopically guided procedures, specifically cholecystectomy, was undertaken because of the decrease in postoperative complications. There are very few studies that have documented this. One such study by Mealy $e t a .^{14}$ involved a prospective cohort comparison of 21 patients at two institutions, and the other, by Ali and Gana, involved a retrospective comparison of 26 patients, though at the same institution. ${ }^{15}$ Both studies showed differences in pain and narcotic requirements though this took $24 \mathrm{hr}$ or longer to become apparent. Both studies also documented improvements in pulmonary function, in terms of vital capacity, forced expiratory volume, peak flow, and functional residual capacity, though again, differences in some variables required $24 \mathrm{hr}$ to become apparent. Since pain and its sequellae are still important after laparoscopic cholecystectomy in the immediate postopera- tive period, optimum patient management should include a multimodal approach. This involves the use of systemic narcotics and nonsteroidal anti-inflammatory agents, local anesthetic injected in the abdomen around the gallbladder, using a 22 gauge spinal nee$\mathrm{dle}$, and into the wound sites, as well as prophylactic use of antiemetics. ${ }^{16}$ This approach has been shown not only to markedly diminish pain immediately postoperatively, but to decrease time spent in the postanesthetic care unit, total time to discharge, as well as improvements in functional activity at $48 \mathrm{hr}$.

\section{(pi) Pediatrics}

Laparoscopic approaches are now being utilized in pediatric patients to perform mainly inguinal herniorraphy though a variety of other procedures have been undertaken. The enthusiasm to adopt this technique utilized in adults however has been lacking in pediatric surgeons. This relates to concerns that pediatric patients may not tolerate the physiologic changes as easily as adults. Furthermore, virtually all of the studies of laparoscopic surgery have involved adult patients. One of the few studies of pediatric patients, that by Gueugniaud et al..$^{17}$, studied children aged 6-30 mo undergoing laparoscopy for orchidopexy. Using noninvasive measurement techniques these authors were able to document similar falls in cardiac output as well as increases in SVRI in their children to those that occur in adults with the creation of the pneumoperitoneum and adoption of the reverse Trendelburg position. With these changes there was however no change in mean arterial pressure, unlike the increase in mean arterial pressure that occurred in adult patients. There were similar decreases in airway compliance and marked increases in airway pressures as had occurred in adults. The authors concluded that this was therefore a safe technique in pediatric patients.

\section{Other Procedures}

\section{(i) Hysteroscopy}

One such procedure that is significantly different from laparoscopic procedures is that of hysteroscopy. The main difference being that a liquid instead of a gas is utilized to distend the uterus and thus allow visualization. This medium is used because of the high vascularity of the uterus in which case gases would readily be absorbed thus producing significant emboli. Therefore, in terms of its complications the procedure resembles that of a transurethral resection of the prostate. These complications include fluid overload and those specifically related to the fluid chosen as shown in Table IV. The ideal fluid, is one that allows good visualization, is non-combustible and produces 
TABLE IV Comparison of solutions used in hysteroscopy

\begin{tabular}{llllll}
\hline & glycine & dextrose & sorbitol & dextran & $\begin{array}{l}\text { carbon } \\
\text { dioxide }\end{array}$ \\
emboli & no & no & no & no & yes \\
visualization & ++ & + & ++ & ++ & ++ \\
cautery & yes & yes & yes & yes & no \\
fluid overload & yes & yes & yes & yes & no \\
problem & CNS & hyper- & hyper- & allergic & smoke \\
& toxicity & glycemia & glycemia & & \\
\hline
\end{tabular}

minimal embolic problems. Dextrose and sorbitol (a sugar that is converted in the liver to fructose and glucose) have not been commonly utilized because of their ability to produce hyperglycemia, while dextran has not been utilized because of its potential to cause allergic reactions. The most commonly utilized fluid is one which contains glycine as with transurethral resection of the prostate. Significant systemic absorption of glycine can cause glycine toxicity which includes blindness and seizures which is thought to be due to glycine's conversion to ammonia. ${ }^{18,19}$

\section{(ii) Thoroscopy}

Diagnostic thoroscopy is also not a new technique. Procedures have been performed for several decades, however, in the last decade improvement in surgical instrumentation has allowed lung resections to be routinely performed with this technique. Such resections involve one lung ventilation in the lateral decubitus position and present the same intraoperative challenges as a standard thoracotomy and can be reviewed elsewhere. One procedure, sympathectomy for hyperhidrosis or upper extremity pain syndromes, is different from a complication perspective. Though the prevalence of this procedure is low in North America, it does appear to be a common procedure in Europe. This procedure is usually performed in otherwise healthy patients, who with the initiation of one lung ventilation can develop severe hypoxia. ${ }^{20}$ This occurs because the procedure involves one lung ventilation in the supine position and hence the gravitational benefit of the lateral decubitus position and perfusion of the dependent, ventilated lung is lost. This problem can be alleviated simply by utilizing the reverse Trendelenburg position at an angle of 60 to 70 degrees. ${ }^{21}$ Cardiovascular surgeons are also utilizing thoroscopy to mobilize the left internal mammary artery which is then anastomosed under direct vision via a small thoracotomy to the left anterior descending coronary artery. ${ }^{22}$ This creates a difficult intraoperative management scenario of one lung ventilation in patients with severe coronary artery disease.

\section{(iii) Neurosurgical procedures}

Neurosurgeons are also experimenting with minimally invasive surgery both intracranially and intraspinally. Intracranial use has been limited to visualization of the ventricular system for treatment of hydrocephalus, or for diagnostic procedures in combination with stereotactic surgery. ${ }^{23}$ These patients would potentially have the complicating factor of raised intracranial pressure, which needs to be appropriately managed. Spinal procedures have been limited to lumbar discectomy. Initially, this involved a posterior lateral approach but technical limitations have limited success rates to 60 $90 \%{ }^{24}$ More recently, anterior laparoscopic approaches have been advocated, however for low lumbar discs $\left(\mathrm{L}_{4}\right.$ $L_{5}$ ) retraction of the aortoiliac bifurcation is required. ${ }^{25}$ Larger studies are therefore necessary before this procedure can be advocated.

As the shift in performing procedures laparoscopically or via minimally invasive approaches continues to increase so, of course, has the complication rate from the surgical perspective. ${ }^{3}$ The British experience has seen an increase, at least from laparoscopic cholecystectomies, in the incidence of early bile leaks and benign stricture formation. Similarly, there has been a corresponding increase in British litigation rates as reported over the last seven years. ${ }^{26}$ Hopefully, these are transient phenomena that will plateau or fall as surgeons become more skilled with the various techniques. Interestingly, there does not however appear to have been a similar increase in anesthetic related complications over this same time period in spite of the pathophysiologic changes that occur intraoperatively as have been noted in this review.

\section{References}

I Berci G. History of pneumoperitoneum. In: Rosenthal RJ, Friedman RL, Phillips EH (Eds.). The

Pathophysiology of Pneumoperitoneum, 1st ed. Berlin: Springer-Verlag, 1998: 1-6.

2 Nash JM. The kindest cuts of all. Time 1992; March 23: 48-9.

3 Johnston A. Laparoscopic surgery. Lancet 1997; 349: 631-5.

4 Joris JL. Anesthetic management of laparoscopy. In: Miller RD (Ed.). Anesthesia, 3rd ed. New York: Churchill Livingstone Inc., 1990: 2011-29.

5 Cunningham AJ, Brull SJ. Laparoscopic cholecystectomy: anesthetic implications. Anesth Analg 1993; 76: 1120-33.

6 Lobato EB, Paige GB, Brown MM, Bennett B, Davis JD. Pneumoperitoneum as a risk factor for endobronchial 
intubation during laparoscopic gynecologic surgery. Anesth Analg 1998; 86: 301-3.

7 Wabba RWM, Tessler MJ, Kleiman SJ. Acute ventilatory complications during laparoscopic upper abdominal surgery. Can J Anaesth 1996; 43: 77-83.

8 Rudston-Brown B, Draper PN, Warriner B, Walley KR, $P$ Pang $P T$. Venous gas embolism - a comparison of carbon dioxide and helium in pigs. Can J Anaesth 1997; 44: 1102-7.

9 Beck DH, McQuillan PJ. Fatal carbon dioxide embolism and severe hemorrhage during laparoscopic salpingectomy. Br J Anaesth 1994; 72: 243-45.

10 Mann C, Boccara G, Grevy V, Navarro F, Fabre JM, Colson $P$. Argon pneumoperitoneum is more dangerous than $\mathrm{CO}_{2}$ pneumoperitoneum during venous gas embolism. Anesth Analg 1997; 85: 1367-71.

11 Couture $P$, Boudreault $D$, Girard $F$, Girard D, Ratele $R$. Hemodynamic effects of mechanical peritoneal retraction during laparoscopic cholecystectomy. Can J Anaesth 1997; 44: 467-72.

12 Koivusalo AM, Kellokumpu I, Ristkari S, Lindgren L. Splanchnic and renal deterioration during and after laparoscopic cholecystectomy: a comparison of the carbon dioxide pneumoperitoneum and the abdominal wall lift method. Anesth Analg 1997; 85: 886-91.

13 Koivusalo AM, Kellokunpu I, Scheinin M, Tikkanen I, Makisalo $H$, Lindgren $L$. A comparison of gases mechanical and conventional carbon dioxide pneumoperitoneum methods for laparoscopic cholecystectomy. Anesth Analg 1998; 86: 153-8.

14 Mealy $K$, Gallagher $H$, Barry $M$, Lennon $F$, Trayner $O$, Hyland J. Physiologic and metabolic responses to open and laparoscopic cholecystectomy. Br J Surg 1992; 79: $1061-4$.

15. Ali J, Gana TJ. Lung volumes $24 \mathrm{~h}$ after laparoscopic cholecystectomy - justification for early discharge. Can Respir J 1998; 5: 109-13.

16 Michaloliakou C, Chung F, Sharma S. Preoperative multimodal analgesia facilitates recovery after ambulatory laparoscopic cholecystectomy. Anesth Analg 1996; 82: 44-51.

17 Gueugniaud PY, Abisseror M, Moussa $M$, et al. The hemodynamic effects of pneumoperitoneum during laparoscopic surgery in healthy infants: assessment by continuous esophageal aortic blood flow echo Doppler. Anesth Analg 1998; 86: 290-3.

18 Levin $H$, Ben-David B. Transient blindness during hysteroscopy: a rare complication. Anesth Analg 1995; 81: 880-1.

19 Ananthanarayan C, Paek W, Rolbin SH, Dhanidina K. Hysteroscopy and anaesthesia. Can J Anaesth 1996; 43: 56-64.

20 Katz $\Upsilon$, Zisman E, Isserles $S A$, Rozenberg B. Left, but not right, one lung ventilation causes hypoxemia during endoscopic transthoracic sympathectomy. J Cardiothorac Vasc Anesth 1996; 10: 207-9.

21 Rozenberg B, Katz $\Upsilon$, Isserles $S A$, Baitman B. Near-sitting position and two lung ventilation for endoscopic transthoracic sympathectomy. J Cardiothorac Vasc Anesth 1996; 10: 210-2.

22 Wasnick JD, Hoffman WJ, Acuff T, Mack $M$. Anesthetic management of coronary artery bypass via minithoracotomy with video assistance. J Cardiothorac Vasc Anesth 1995; 9:731-3.

23 Bauer BL, Hellwig D. Minimally invasive endoscopic neurosurgery - a survey. Acta Neurochir 1994; 61(Suppl): 1-12.

24 Zelko JR, Misko J, Swanstrom C, Pennings J, Kenyon T. Laparoscopic lumbar discectomy. Am J Surg 1995; 169: 196-8.

25 Cloyd DW, Obenchain TJ, Sabin M. Transperitoneal laparoscopic approach to lumbar discectomy. Surg Laparosc Endosc 1995; 5: 85-9.

26. Goodwin $H$. Minimal access surgery. International Journal of the Medical Defence Union 1998; 12: 1-3. 


\section{L'anesthésie pour la chirurgie à caractère effractif minimal}

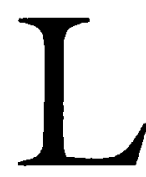

A présente revue se veut un résumé des implications de la chirurgie à caractère effractif minimal qui comprend de nombreuses opérations réalisées grâce à la visualisation et à l'instrumentation indirectes. Beaucoup ne sont pas nouvelles : des descriptions de laparoscopie remontent au début des années 1900 (Berci). ${ }^{1}$ $\mathrm{Ce}$ sont les récents progrès technologiques dans le câblage de la fibre optique autant que dans l'instrumentation microchirurgicale qui ont permis l'utilisation de ces techniques pour de multiples interventions toujours plus complexes. Cependant, cette technologie est coûteuse et n'aurait sans doute pas été adoptée si le public n'en avait perçu et compris les bénéfices (Nash) ${ }^{2}$ Notre revue décrira d'abord la laparoscopie, puisque c'est l'intervention à caractère effractif minimal la plus étudiée et connue, et elle mettra ensuite en lumière d'autres modalités en insistant sur les variations spécifiques entre ces modalités et la laparoscopie.

\section{Chirurgie laparoscopique}

Depuis les années 1970, la chirurgie laparoscopique abdominale basse, gynécologique surtout, est régulièrement réalisée. Pendant les années 1990,

TABLE I Comparaison entre laparoscopie et laparotomie pour la cholécystectomie

\begin{tabular}{|c|c|c|}
\hline Variable & Laparoscopie & Laparotomie \\
\hline \multicolumn{3}{|l|}{$\begin{array}{l}\text { Peropératoire } \\
\text { changements respiratoires }\end{array}$} \\
\hline volumes pulmonaires & ++ & + \\
\hline $\begin{array}{l}\text { compliance } \\
\text { changements }\end{array}$ & ++ & + \\
\hline cardiovasculaires & ++ & + \\
\hline position & Trendelenburg inversée & $\begin{array}{l}\text { décubitus } \\
\text { dorsal }\end{array}$ \\
\hline absorption de $\mathrm{CO}_{2}$ & ++ & - \\
\hline Postopératoire & & \\
\hline $\begin{array}{l}\text { douleur } \\
\text { dysfonctionnement }\end{array}$ & + & ++ \\
\hline pulmonaire & + & ++ \\
\hline réponse métabolique & + & ++ \\
\hline $\begin{array}{l}\text { nausées et vomissements } \\
\text { séjour à l'hópital }\end{array}$ & $\begin{array}{l}++ \\
\text { externe }\end{array}$ & $\begin{array}{l}+ \\
\text { interne }\end{array}$ \\
\hline
\end{tabular}

Neal H. Badner MD FRCPC

l'amélioration des instruments a fait en sorte que la cholécystectomie laparoscopique a révolutionné la chirurgie abdominale haute. Maintenant, l'herniorraphie et les interventions gastro-œesophagienne, hépato-biliaire ou colo-rectale, même les interventions spléniques, réalisées par laparoscopie, sont régulièrement pratiquées en utilisant des explorations peu effractives. ${ }^{3}$ Les raisons de ce changement sont résumées à la Table I. Essentiellement, les complications postopératoires, douleur, dysfonctionnement pulmonaire, réaction métabolique, fatigue et séjour prolongé à l'hôpital, qui se produisent avec la laparotomie, sont réduites avec la laparoscopie au prix d'une physiopathologie peropératoire accrue touchant le système cardiorespiratoire, l'absorption de gaz carbonique et le positionnement du patient. ${ }^{4} \mathrm{Ce}$ qui a d'abord entraîné la contre-indication de la cholécystectomie laparoscopique dans les cas de maladie cardiopulmonaire ou d'obésité morbide. ${ }^{5}$ Toutefois, l'amélioration des résultats postopératoires en fait à présent l'intervention de choix pour les patients atteints de maladie pulmonaire.

\section{(i) Effets pulmonaires}

Les changements pulmonaires, pendant les interventions laparoscopiques, dépendent surtout de la position du patient et de la création d'un pneumopéritoine. $\mathrm{Ce}$ dernier (qui devrait se limiter à $15 \mathrm{mmHg}$ ) provoque la diminution des volumes pulmonaires qui pourrait entraîner un affaissement des alvéoles pulmonaires et de l'hypoxie. Le pneumopéritoine réduit aussi la compliance, augmentant le travail de la respiration et gênant ainsi la ventilation. En outre, le pneumopéritoine est créé avec du gaz carbonique $\left(\mathrm{CO}_{2}\right.$, voir plus bas) qui, rapidement absorbé, doit être éliminé par les poumons. Cette situation accroît les besoins de ventilation et également la stimulation du système nerveux sympathique. Dans le contexte de la ventilation, la position du patient, qui est celle de Trendelenburg (tête en bas) pour la chirurgie abdominale basse, diminue encore les volumes pulmonaires et augmente le travail respiratoire. Pour la chirurgie abdominale haute, on utilise la position de 
Trendelenburg inversée (tête vers le haut), ce qui contrebalance l'effet du pneumopéritoine en augmentant les volumes pulmonaires et en facilitant le travail respiratoire. Le résultat net du pneumopéritoine et de la position de Trendelenburg inversée, est une hausse de pression partielle du gaz carbonique $\left(\mathrm{PaCO}_{2}\right)$ et de pression partielle du gaz carbonique de fin d'expiration $\left(\mathrm{P}_{\mathrm{ET}} \mathrm{CO}_{2}\right)$ d'environ $8 \mathrm{mmHg}$ et une augmentation du $\mathrm{pH}$ de 0,01 unité. ${ }^{4}$ C'est accompagné d'un accroissement de la pression plateau des voies aériennes de 10 $\mathrm{cm}$ de $\mathrm{H}_{2} \mathrm{O}$ et d'une réduction de $50 \%$ de la compliance des poumons. Quand la situation est prévue, ces changements sont facilement compensés par la ventilation mécanique contrôlée.

\section{(ii) Changements cardiopasculaires}

L'examen de l'aspect cardiovasculaire indique que le pneumopéritoine diminue le retour veineux et, de ce fait, l'index cardiaque, tout en augmentant la résistance vasculaire générale et, donc, la pression artérielle moyenne. La position de Trendelenburg provoque l'augmentation du retour veineux et du volume systolique tandis que la position inversée aggrave les changements cardiovasculaires induits par le pneumopéritoine en diminuant encore plus le retour veineux. Comme on l'a déjà dit, l'accroissement de la pression intra-abdominale conduit à une diminution du retour veineux autant qu'à une diminution de la résistance vasculaire générale. ${ }^{4}$ Cet effet se fait sentir en moins de cinq minutes après le début du pneumopéritoine et, bien qu'il décroisse avec le temps, il agit toujours $\mathbf{3 0}$ min après le début du pneumopéritoine. Dans

TABLE III Caractéristiques des gaz utilisés pour le pneumopéritoine

\begin{tabular}{llllll}
\hline \multicolumn{7}{c}{$\begin{array}{c}\text { Gaz } \\
\text { carbonique }\end{array}$} & $\begin{array}{l}\text { Protoxyde } \\
\text { d'azote }\end{array}$ & Air Argon & Hélium & Oxygène \\
\hline hydrosolubilité & oui & non & non non & non & non \\
combustible & non & oui & oui non & non & oui \\
inerte & non & oui & oui oui & oui & non \\
irritation & oui & non & oui non & non & oui \\
\hline
\end{tabular}

la situation alors créée, l'index cardiaque est abaissé, mais la pression artérielle moyenne est élevée. Les patients atteints de maladie cardiovasculaire sévère et de dysfonctionnement du ventricule gauche peuvent avoir besoin de monitorage effractif avec l'emploi de cathéters artériels et de l'artère pulmonaire.

\section{(iii) Complications}

Certaines complications existent qui, sans être uniques à la chirurgie laparoscopique abdominale, y sont plus courantes. Elles comprennent l'intubation endobronchique, le pneumothorax, l'emphysème souscutané et l'embolie gazeuse massive $\left(\mathrm{CO}_{2}\right)$. Leur survenue peut être soudaine et avoir des conséquences mortelles. Leur différenciation, résumée à la Table II, est déterminée par les mesures du capnographe, de l'oxymètre de pouls et de la pression des voies aériennes.

L'intubation endobronchique peut être nécessaire pendant l'opération et est généralement reliée dans le temps aux changements de position du patient, surtout à l'introduction du pneumopéritoine et de la position de Trendelenburg. ${ }^{6}$ Les conséquences, élévation de la pression des voies aériennes et désaturation, se manifestent donc tôt d'habitude pendant l'intervention, et sans augmentation de la $\mathrm{P}_{\mathrm{ET}} \mathrm{CO}_{2}$.

Le développement d'un pneumothorax survient généralement plus tard pendant l'intervention et est associé à une hausse de la $\mathrm{P}_{\mathrm{ET}} \mathrm{CO}_{2}$, comme l'emphysème sous-cutané qui l'accompagne, et il est plus courant lors des opérations de l'oesophage. ${ }^{7}$ On traite généralement le pneumothorax par l'insertion d'un drain thoracique. Cépendant, à la suite de leur grande série, Joris et coll. ont recommandé d'essayer initialement d'augmenter la concentration d'oxygène inspiré, de discontinuer le protoxyde d'azote et d'ajouter de la pression expiratoire positive. ${ }^{4}$ Cette recommandation tient compte du fait que la mise en place de drain thoracique pourrait évacuer le pneumopéritoine et rendre pratiquement impossible la fin de l'opération.

Un important emphysème sous-cutané, également plus répandu lors d'opérations de l'œsophage, peut aussi se produire de façon indépendante et, en général,

TABLE II Algorithme permettant la différenciation des complications importantes de la chirurgie laparoscopique

\begin{tabular}{lllll}
\hline capnographie & $\pm \mathrm{P}_{\mathrm{ET}} \mathrm{CO}_{2}$ & $\uparrow \mathrm{P}_{\mathrm{ET}} \mathrm{CO}_{2}$ & $\uparrow \mathrm{P}_{\mathrm{ET}} \mathrm{CO}_{2}$ & $\downarrow \mathrm{P}_{\mathrm{ET}} \mathrm{CO}_{2}$ \\
oxymétrie & $\downarrow \mathrm{SaO}_{2}$ & $\downarrow \mathrm{SaO}_{2}$ & - & $\downarrow$ \\
$\mathrm{P}$ voies aériennes & $\uparrow \mathrm{PVA}$ & $\uparrow \mathrm{SaO}_{2}$ & - \\
-autre & $\downarrow$ entrée d'air & $\downarrow$ entrée d'air & crépitations & $\begin{array}{l}\text { souffle, } \downarrow \mathrm{TA} \\
\text { changements ECG } \\
\text { diagnostic }\end{array}$ \\
& $\begin{array}{l}\text { intubation } \\
\text { endobronchique }\end{array}$ & pneumothorax & emphysème & $\begin{array}{l}\text { embolie } \\
\text { massive au } \mathrm{CO}_{2}\end{array}$ \\
\hline
\end{tabular}


plus tard pendant l'intervention. Il provoque une élévation soudaine de la $\mathrm{P}_{\mathrm{ET}} \mathrm{CO}_{2}$, mais sans modification de la saturation en oxygène du sang artériel ou de la pression des voies aériennes. L'augmentation de gaz carbonique artériel peut être assez rapide et importante, se modifiant en moins de $\mathbf{3 0} \mathrm{min}$. Sa résolution est plutôt précoce après l'intervention, moins de $\mathbf{1 2 0}$ min habituellement.

Finalement, même si les microembolies au $\mathrm{CO}_{2}$ sont assez répandues, selon les résultats d'échocardiographies transoesophagiennes, les embolies massives, suffisantes pour obstruer la voie d'éjection pulmonaire, sont plutôt rares. Quand elles surviennent, il y a généralement une diminution soudaine de $\mathrm{P}_{\mathrm{ET}} \mathrm{CO}_{2}$ combinée à une chute rapide de saturation en oxygène, sans changement de pression des voies aériennes. ${ }^{9}$

\section{(iv) Visualisation}

Comme nous l'avons dit déjà, les chirurgiens doivent créer un pneumopéritoine pour visualiser les viscères abdominaux. Pour ce faire, on utilise d'habitude le gaz carbonique. Choisi pour sa grande solubilité dans l'eau, il permet l'élimination facile, par les poumons, du gaz absorbé tout en réduisant les effets d'une embolie gazeuse. Il est aussi incombustible, ce qui permet d'employer la cautérisation (Table III). On a largement abandonné le protoxyde d'azote, l'air et l'oxygène qui peuvent entretenir la combustion. Des expériences récentes ont porté sur l'usage de gaz inertes, l'hélium et l'argon, qui sont incombustibles et n'irritent pas l'abdomen. Ces gaz sont aussi extrêmement insolubles, ce qui peut créer des problèmes en cas d'embolie gazeuse. Des études sur les animaux qui comparaient l'emploi de gaz inertes et de gaz carbonique dans le pneumopéritoine ont montré que les gaz inertes étaient beaucoup plus dangereux quand l'embolie se formait. ${ }^{8,10}$ La plus récente innovation est l'utilisation d'un rétracteur de la paroi abdominale qui permet de la soulever et de voir les viscères sans créer de pneumopéritoine. ${ }^{11-13}$ L'usage de ce rétracteur élimine la réduction de compliance et des volumes pulmonaires, évite la charge de gaz carbonique et réduit les changements du retour veineux et de la résistance vasculaire généralisée. Il faut encore vérifier si ce dispositif peut être acceptable en chirurgie.

\section{(p) Résultats}

Le passage de la laparotomie aux interventions laparoscopiques, la cholécystectomie en particulier, a été guidé par la diminution des complications postopératoires. Très peu d'études documentent cette situation. Une d'entre elles, par Mealy et coll. ${ }^{14}$, établit la com- paraison prospective d'une cohorte de 21 patients dans deux institutions, et l'autre étude, par Ali et Gana, une comparaison rétrospective de 26 patients, mais à la même institution. ${ }^{15}$ Les études ont montré des besoins différents de sédatifs et de narcotiques, devenus apparents toutefois après $24 \mathrm{~h}$ ou plus. Les études ont aussi montré des améliorations de la fonction pulmonaire, en termes de capacité vitale, volume expiratoire maximum-seconde, débit de pointe et capacité résiduelle fonctionnelle, qui, de nouveau, sont apparues après $24 \mathrm{~h}$ pour certaines variables. $\mathrm{La}$ douleur et ses séquelles étant toujours importantes immédiatement après une cholécystectomie laparoscopique, le traitement optimal du patient doit comporter une thérapie multimodale. Cela comprend l'emploi de narcotiques systémiques et d'anti-inflammatoires non stéroïdes, d'anesthésique local injecté dans l'abdomen dans la région vésiculaire, à l'aide d'une aiguille rachidienne de calibre 22 , et dans les plaies chirurgicales, autant que l'utilisation prophylactique d'antiémétiques. ${ }^{16}$ Cette méthode a été reconnue pour, non seulement diminuer de façon marquée la douleur postopératoire immédiate, mais aussi pour réduire le temps passé à la salle de réveil et le temps total d'hospitalisation ainsi que pour améliorer l'activité fonctionnelle après $48 \mathrm{~h}$.

\section{(vi) Pédiatrie}

Les interventions laparoscopiques sont maintenant utilisées chez les patients pédiatriques, surtout lors d'herniorraphie inguinale, quoiqu'une variété d'autres interventions soit possible. L'enthousiasme à adopter cette technique fait cependant défaut aux chirurgiens pédiatriques. On semble craindre que les enfants ne puissent tolérer les changements physiologiques autant que les adultes. En outre, presque toutes les études sur la chirurgie laparoscopique portent sur les adultes. L'une des rares études d'enfants, de Gueugniaud et coll. ${ }^{17}$, concernait des patients de 6-30 mois qui devaient subir une laparoscopie pour orchidopexie. En utilisant des techniques de mesure non effractives, on a démontré des chutes de débit cardiaque de même que des augmentations de l'IRVS (index de résistance vasculaire systémique) similaires à celles qui surviennent chez les adultes avec le pneumopéritoine et la position de Trendelenburg inversée. Par ailleurs, il n'y avait pas de changement de pression artérielle moyenne, contrairement à l'augmentation survenue chez les adultes. Mais il y a eu, comme chez les adultes, des réductions de compliance et des baisses marquées de pression des voies aériennes. Les auteurs concluent que c'est donc une technique sûre chez les patients pédiatriques. 
TABLE IV Comparaison des solutions utilisées pour l'hystéroscopie

\begin{tabular}{|c|c|c|c|c|c|}
\hline & glycine & dextrose & sorbitol & dextran & $\begin{array}{l}\text { gaz } \\
\text { car- } \\
\text { bonique }\end{array}$ \\
\hline \multirow{5}{*}{$\begin{array}{l}\text { embolie } \\
\text { visualisation } \\
\text { cautérisation } \\
\text { surcharge liquide } \\
\text { problème }\end{array}$} & non & non & non & non & oui \\
\hline & ++ & + & ++ & ++ & ++ \\
\hline & oui & oui & oui & oui & non \\
\hline & oui & oui & oui & oui & non \\
\hline & $\begin{array}{l}\text { toxicité } \\
\text { SNC }\end{array}$ & $\begin{array}{l}\text { hyper- } \\
\text { glycémie }\end{array}$ & $\begin{array}{l}\text { hyper- } \\
\text { glycémie }\end{array}$ & allergie & fumée \\
\hline
\end{tabular}

\section{Autres interventions chirurgicales}

\section{(i) Hystéroscopie}

Une des interventions à distinguer de façon significative de la laparoscopie, est l'hystéroscopie. La principale différence étant qu'un liquide, plutôt qu'un gaz, est utilisé pour distendre l'utérus et ainsi permettre la visualisation. Ce choix tient compte de la grande vascularité de l'utérus où les gaz pourraient être rapidement absorbés et produire une embolie importante. En termes de complications, l'hystéroscopie s'apparente donc à la prostatectomie transurétrale. Ces complications sont une surcharge de liquide et d'autres effets liés au liquide choisi, comme le montre la Table IV. Le liquide idéal permet une bonne visualisation, est incombustible et produit le moins de problèmes liés à l'embolie. Le dextrose et le sorbitol (sucre converti dans le foie en fructose et en glucose) sont peu utilisés à cause de la possibilité d'hyperglycémie, tandis que le dextran n'est pas employé parce qu'il pourrait causer des réactions allergiques. Le liquide le plus utilisé, comme dans le cas de la prostatectomie transurétrale, contient de la glycine. L'absorption significative de glycine peut causer de l'intoxication à la glycine, incluant la cécité et des convulsions qu'on croit liées à la conversion de la glycine en ammoniac.

\section{(ii) Thoracoscopie}

La thoracoscopie diagnostique n'est pas, non plus, une nouvelle technique. Des opérations sont pratiquées depuis quelques décennies mais, au cours des dix dernières années, l'amélioration des instruments chirurgicaux a permis de faire régulièrement des résections pulmonaires grâce à cette technique. Cela demande la ventilation d'un seul poumon, le patient étant en décubitus latéral, et représente les mêmes défis peropératoires qu'une thoracotomie standard, défis qu'on pourra revoir ailleurs dans la littérature. Autre intervention, la sympathectomie, pour traiter l'hyperhidrose ou des syndromes de douleur du mem- bre supérieur, présente des complications différentes. Même si la prévalence de cette intervention est faible en Amérique du Nord, elle semble fréquente en Europe. On l'utilise généralement chez des patients par ailleurs en santé qui, avec le début de la ventilation à un seul poumon, peuvent développer une sévère hypoxie. ${ }^{20}$ Cela se produit parce que l'intervention exige la ventilation à un seul poumon avec le patient en décubitus dorsal et que, par conséquent, l'avantage gravitationnel du décubitus latéral du poumon déclive et ventilé est perdu. Ce problème peut être atténué en utilisant simplement la position de Trendelenburg inversée avec un angle de 60 à 70 degrés. ${ }^{21}$ Les chirurgiens cardiovasculaires utilisent aussi la thoracoscopie pour mobiliser l'artère mammaire interne gauche qui est ensuite anastomosée à l'artère interventriculaire antérieure, sous visualisation directe, au moyen d'une petite thoracotomie. ${ }^{22}$ Cela crée une situation de gestion peropératoire difficile, avec ventilation à un seul poumon, chez des patients atteints de sévère cardiopathie ischémique.

\section{(iii) Interventions neurochirurgicales}

Les neurochirurgiens font aussi l'expérience de la chirurgie à caractère effractif minimal intracrânienne et intrarachidienne. L'utilisation intracrânienne a été limitée à la visualisation du système ventriculaire dans le but de traiter l'hydrocéphalie ou à des modalités diagnostiques en combinaison avec la chirurgie stéréotaxique. ${ }^{23}$ Les patients peuvent subir une élévation de la pression intracrânienne, complication qui doit être adéquatement traitée. L'utilisation rachidienne s'est limitée à la discectomie lombaire. Cela implique initialement une approche latérale postérieure, mais des limites techniques ont maintenu le taux de réussite entre 60 et $90 \%{ }^{24}$ Plus récemment, les approches laparoscopiques antérieures ont été conseillées, quoique pour les disques lombaires inférieurs $\left(\mathrm{L}_{4}-\mathrm{L}_{5}\right)$ la rétraction de la bifurcation aorto-iliaque soit exigée. ${ }^{25}$ Une grande série est donc nécessaire avant que cette intervention ne puisse être recommandée.

Comme les interventions laparoscopiques, ou au moyen d'exploration à caractère effractif minimal, augmentent de plus en plus, le taux de complications chirurgicales fait de même. ${ }^{3}$ L'expérience britannique montre une augmentation, du moins à partir des données des cholécystectomies laparoscopiques, de l'incidence de fuite biliaire précoce et de sténose bénigne. De la même manière, il y a eu un accroissement correspondant de litiges en Grande-Bretagne comme on le rapporte depuis les sept dernières années. ${ }^{26}$ Heureusement, c'est un phénomène transitoire qui va se stabiliser ou diminuer à mesure que les chirurgiens 
deviendront plus habiles avec les diverses techniques. Fait intéressant, il ne semble pas cependant qu'il y ait une augmentation semblable de complications reliées à l'anesthésie pendant cette même période en dépit des changements physiopathologiques peropératoires tel qu'on l'a noté dans cette revue.

\section{Références}

(Voir page R104) 